ISSN 1411 - 0067 Jurnal Ilmu-Ilmu Pertanian Indonesia. Volume 9, No. 1, 2007, Hlm. 20 - 31

\title{
PERBEDAAN SIFAT-SIFAT TANAH VERTISOL DARI BERBAGAI BAHAN INDUK
}

\section{DIFFERENTIATION IN PROPERTIES OF VERTISOL FROM VARIOUS PARENT MATERIALS}

\author{
B. H. Prasetyo \\ Balai Besar Penelitian dan Pengembangan Sumberdaya Lahan Pertanian \\ Jl. Ir. H. Juanda 98 Bogor 16123, Indonesia \\ csar@indosat.net.id
}

\begin{abstract}
Vertisols is black and fertile soils, derived from various parent materials, dominated by smectite clay minerals, and charasterize by crack formation during dry season. Six soil profiles consisted of thirty two soil samples from dIfferent location were analyzed for their chemical and mineralogical composition at the laboratories of Soil Research Center for soil characteristics. Results indicate that the color matrix of Vertisols varies, hue range from $2.5 \mathrm{Y}$ to $10 \mathrm{YR}$, color value varies from 2 to 6 , and chroma range from 0 to 4 . Clay mineral composition of Vertisols is dominated by smectite. Other clay minerals founded in the Vertisols are kaolinite, illite and vermiculite. The mineralogy composition of sand fraction is varies, some of them rich in weatherable minerals like andesine, amfibole, orthoclase, sanidin and the others are dominated by resistant minerals such as quartz and opaque. The mineralogical composition of Vertisols dependent on their parent material. The dominant cations in Vertisols are $\mathrm{Ca}^{++}$and $\mathrm{Mg}^{++}$. Vertisols from volcanic materials is dominated by $\mathrm{Ca}^{++}$and followed by $\mathrm{Mg}^{++}$cations, Vertisols from limestone is dominated by $\mathrm{Ca}^{++}$, while Vertisols from peridotite is dominated by $\mathrm{Mg}^{++}$. All of the Vertisols studied have a high cation exchange capacity with pH's range from 5.5 to 7.4. In using Vertisols for food plantation, should be consider the high content of $\mathrm{Ca}^{++}, \mathrm{Mg}^{++}$and the water management. The soils should be atleast always in moist condition, otherwise soils become very hard and cracks when dry.
\end{abstract}

Key words: parent materials, smectite, Vertisols

\begin{abstract}
ABSTRAK
Vertisol adalah tanah hitam dan subur, dapat terbentuk dari berbagai macam bahan induk tanah, mineral liatnya didominasi oleh smektit, dan mempunyai sifat yang retak-retak bila kering. Enam profil tanah Vertisol dari lokasi dan bahan induk berbeda, yang terdiri dari 32 contoh tanah telah dianalisis sifat kimia dan komposisi mineralnya di Laboratorium Balai Penelitian Tanah untuk keperluan karakterisasi tanah. Hasil karakterisasi menunjukkan bahwa warna tanah Vertisol bevariasi, denganhue berkisar dari 2.5Y hingga 10YR, value bervariasi dari 2 hingga 6, dan kroma berkisar dari 0 hingga 4. Mineral liat didominasi oleh smektit, dengan sedikit kaolinit, illit atau vermikulit. Komposisi mineral fraksi pasir bervariasi, beberapa pedon (P2 dan P6) kaya akan kandungan mineral mudah lapuk seperti andesin, amfibol, orthoklas, sanidin, dan beberapa pedon lainnya didominasi oleh mineral resisten seperti kuarsa dan opak (P4 dan P5). Kation dapat ditukar yang mendominasi Vertisol sangat tergantung pada bahan induk tanahnya. Vertisol yang berasal dari bahan volkan didominasi oleh kation dapat tukar $\mathrm{Ca}^{++}$ diikuti oleh $\mathrm{Mg}^{++}$, yang berasal dari batu gamping didominasi oleh $\mathrm{Ca}^{++}$, sedangkan yang berasal dari ultrabasa peridotit didominasi oleh $\mathrm{Mg}^{++}$. Nilai kapasitas tukar kation dari Vertisol tergolong tinggi hingga sangat tinggi dengan $\mathrm{pH}$ berkisar antara 5,5 hingga 7,4. Penggunaan tanah ini untuk pertanian harus memperhatikan tingginya kandungan kation $\mathrm{Ca}^{++}$dan $\mathrm{Mg}^{++}$, serta pengelolaan air untuk menghindarkan tanah dari kondisi kering.
\end{abstract}

Kata kunci : bahan induk, smektit, Vertisols 


\section{PENDAHULUAN}

Vertisol adalah tanah yang berwarna abu-abu gelap hingga kehitaman, bertektur liat, mempunyai slickenside dan rekahan yang secara periodik dapat membuka dan menutup. Tanah Vertisol umumnya terbentuk dari bahan sedimen yang mengandung mineral smektit dalam jumlah tinggi, di daerah datar, cekungan hingga berombak (Driessen and Dudal, 1989). Pembentukan tanah Vertisol terjadi melalui dua proses utama, pertama adalah proses terakumulasinya mineral 2:1 (smektit), dan yang kedua adalah proses mengembang dan mengkerut yang terjadi secara periodik sehingga membentuk slickenside atau relief mikro gilgai (van Wambeke, 1992).

Dalam perkembangannya mineral 2:1 yang sangat dominan dan memegang peran penting pada tanah ini. Komposisi mineral liat dari Vertisol selalu didominasi oleh mineral 2:1, biasanya monmorilonit, dan dalam jumlah sedikit sering dijumpai mineral liat lainnya seperti illit dan kaolinit (Ristori et al., 1992). Tanah ini sangat dipengaruhi oleh proses argillipedoturbation, yaitu proses pencampuran tanah lapisan atas dan bawah yang diakibatkan oleh kondisi basah dan kering yang disertai pembentukan rekahan-rekahan secara periodik (Fanning and Fanning, 1989). Prosesproses tersebut menciptakan struktur tanah dan pola rekahan yang sangat spesifik. Ketika basah, tanah menjadi sangat lekat dan palstis serta kedap air, tapi ketika kering, tanah menjadi sangat keras dan masif atau membentuk pola prisma yang terpisahkan oleh rekahan. (Van Wambeke, 1992).

Pada tanah Vertisol umumnya sifat-sifat fisik lebih merupakan kendala dibanding sifat-sifat kimianya. Kendala utama untuk tanaman adalah tektur yang liat berat, sifat mengembang dan mengkerut, kecepatan infiltrasi air yang rendah, serta drainase yang lambat (Mukanda and Mapiki, 2001). Tanah ini juga tergolong rawan erosi (Eswaran and Cook, 1988). Secara kimiawi Vertisol tergolong tanah yang relatif kaya akan hara karena mempunyai cadangan sumberhara yang tinggi, dengan kapasitas tukar kation tinggi dan pH netral hingga alkali (Deckers et al., 2001).

Di daerah tropis, penyebaran Vertisol mencapai 200 juta hektar atau sekitar empat persen dari luas daratan (Dudal and Eswaran, 1988; Driessen and Dudal, 1989). Di Indonesia penyebaran Vertisol mencapai sekitar 2.1 juta hektar (Subagyo et al., 2004), dan tersebar di daerah Jawa Tengah, Jawa Timur, Lombok, Sumbawa, Sumba dan Timor (Subagjo, 1983). Beberapa penelitian mengenai karakteristik tanah Vertisol di Indonesia pernah dilakukan oleh Subagjo (1983), pada Vertisol dari bahan volkan andesitik Gunung Lawu, Prasetyo et al. $(1996,2000)$ pada Vertisol dari bahan volkan andesitik Gunung Arjuno, di Jawa Timur dan dari bahan batu kapur di daerah Pametikarata, Sumba Timur; Mulyanto et al. (2001) pada Vertisol dari batu kapur di Ngawi dan Bojonegoro, Jawa Timur dan Hikmatullah et al. (2002) pada Vertisol dari bahan endapan lakustrin di Gorontalo, Sulawesi Utara.

Tulisan ini bertujuan untuk meneliti berbagai perbedaan Vertisol yang berkembang dari berbagai bahan induk dilihat dari sifat morfologi, mineral dan kimianya.

\section{METODE PENELITIAN}

Untuk bahan penelitian telah digunakan enam buah pedon yang berasal dari bahan induk dan tempat yang berbeda. Lokasi dan bahan induk dari Vertisol yang diteliti disajikan dalam Tabel 1 .

Tabel 1. Pedon, landform, bahan induk dan lokasi pengembilan contoh Vertisol

\begin{tabular}{lllc}
\hline \hline Pedon & Landform & Bahan induk & Lokasi \\
P1 & Dataran aluvial & Aluvim napal & Mangkang Wetan,Ungaran, Jateng \\
P2 & Dataran aluvial & Volkan andesitik & Gedangan, Madiun, Jatim \\
P3 & Dataran banjir & Endapan banjir & Cikarang, Karawang, Jabar \\
P4 & Kaki lereng & Peridotit & Trobulu, Ponggolaku, Sultra \\
P5 & Dataran aluvial & Aluvium gamping & Pametikarata, Lewa, Sumba \\
P6 & Lakustrin & Endapan Lakustrin & Paguyaman,Gorontalo, Sulut \\
\hline
\end{tabular}


Tabel 2. Warna matrik, tekstur, dan klasifikasi tanah Vertisol

\begin{tabular}{|c|c|c|c|c|}
\hline Pedon & Kedalaman (m) & Wama matrik & Tekstur & Klasifikasi Tanah (USDA, 2003) \\
\hline \multirow[t]{4}{*}{ P1 } & $0-24$ & $5 Y 4 / 1$ & H eavy clay & \multirow{4}{*}{$\begin{array}{l}\text { Typic Hapluderts, sangat halus, } \\
\text { montm orillonitik, isohyperthermis }\end{array}$} \\
\hline & $24-49$ & $5 Y 5 / 1$ & Heavy clay & \\
\hline & $49-74$ & $\mathrm{~N} 4 / 0$ & Heavy clay & \\
\hline & $74-99$ & $5 Y 5 / 1$ & Heavy clay & \\
\hline \multirow[t]{6}{*}{ P2 } & $0-18$ & $2.5 \mathrm{Y} 50$ & Heavy clay & \multirow{6}{*}{$\begin{array}{l}\text { Chromic Hapluderts, sangat halus, } \\
\text { montm orillonitik, isohyperthermis }\end{array}$} \\
\hline & $18-36$ & $2.5 \mathrm{Y} 5.0$ & Heavy clay & \\
\hline & $36-56$ & $2.5 \mathrm{Y} 50$ & Heavy clay & \\
\hline & $56-88$ & $2.5 \mathrm{Y} 5 / 1$ & Heavy clay & \\
\hline & $88-105$ & $2.5 \mathrm{Y} 5 / 2$ & Heavy clay & \\
\hline & $105-130$ & $10 \mathrm{YR} 5 / 2$ & Heavy clay & \\
\hline \multirow[t]{5}{*}{ P3 } & $0-16$ & 10YR $4 / 1$ & Heavy clay & \multirow{5}{*}{$\begin{array}{l}\text { Chromic Endoaquerts, sangat } \\
\text { halus, campur an, isohyperthermis }\end{array}$} \\
\hline & $16-40$ & $2.5 \mathrm{Y} 4 / 1$ & Heavy clay & \\
\hline & $40-66$ & $\mathrm{~N} \quad 4,0$ & Heavy clay & \\
\hline & $66-106$ & $\mathrm{~N} \quad 40$ & Heavy clay & \\
\hline & $106-150$ & $2.5 \mathrm{Y} 5 / 1$ & Heavy clay & \\
\hline \multirow[t]{6}{*}{ P4 } & $0-24$ & 10YR $2 / 1$ & Heavy clay & \multirow{6}{*}{$\begin{array}{l}\text { Paleustollic Chromusters, sangat } \\
\text { halus, montmorilloritik, } \\
\text { isohyperthermis }\end{array}$} \\
\hline & $8-24$ & $10 \mathrm{YR} 3 / 3$ & Heavy clay & \\
\hline & $24-48$ & $10 Y R 3 / 4$ & Heavy clay & \\
\hline & $48-72$ & $10 Y R 3 / 4$ & Heavy clay & \\
\hline & $72-109$ & $10 \mathrm{YR} 3 / 4$ & Heavy clay & \\
\hline & $109-130$ & $5 \mathrm{BG} \quad 4 / 1$ & Heavy clay & \\
\hline \multirow[t]{7}{*}{ P5 } & $0-22$ & $7.5 Y R 2 / 0$ & Heavy clay & \multirow{7}{*}{$\begin{array}{l}\text { Udic Haplusterts, sangat halus, } \\
\text { montm orill oritik, isohyperthermis }\end{array}$} \\
\hline & $22-43$ & 7.5 YR 30 & Heavy clay & \\
\hline & $43-62$ & 7.5 YR 310 & Heavy clay & \\
\hline & $62-89$ & 10YR $5 / 1$ & Heavy clay & \\
\hline & $89-110$ & 10YR $5 / 1$ & Heavy clay & \\
\hline & $110-140$ & $10 \mathrm{YR} 6 / 1$ & Heavy clay & \\
\hline & $140-170$ & $10 \mathrm{YR} 6 / 1$ & Heavy clay & \\
\hline \multirow[t]{5}{*}{ P6 } & $0-15$ & $2.5 \mathrm{Y} 5 / 2$ & Heavy clay & \multirow{5}{*}{$\begin{array}{l}\text { Ustic Endooquerts, sangat halus, } \\
\text { campuran, isohyperthermis }\end{array}$} \\
\hline & $15-32$ & $10 \mathrm{YR} 4 / 3$ & Heavy clay & \\
\hline & $32-53$ & $2.5 \mathrm{Y} 5 B$ & Heavy clay & \\
\hline & $53-71$ & $2.5 \mathrm{Y} 5 / 1$ & Heavy clay & \\
\hline & $71-103$ & $2.5 \mathrm{Y} 5 / 1$ & Heavy clay & \\
\hline
\end{tabular}

Untuk keperluan analisis sifat kimia dan mineralogi tanah, 32 contoh tanah telah diambil dan dianalisis di Laboratorium Balai Penelitian Tanah. Analisis sifat fisik dan kimia meliputi tekstur, karbon organik, $\mathrm{pH}\left(\mathrm{H}_{2} \mathrm{O}\right.$ dan $\left.\mathrm{KCl}\right)$, besi bebas (metode dithionit), $\mathrm{P}$ dan $\mathrm{K}$ potensial (25\% $1 \mathrm{~N} \mathrm{HCl}$ ), $\mathrm{P}$ tersedia (Olsen), Retensi $\mathrm{P}$ (Blackmore et al., 1981), kation dapat tukar dan kapasitas tukar kation (1 N NH4OAc, pH 7.0). Analisis dilakukan mengikuti metoda dari Soil Survey Laboratory Staff (1991). Analisis mineralogi dilakukan baik pada fraksi pasir maupun fraksi liat. Mineral fraksi pasir dianalisis menggunakan mikroskop polarisasi dengan metode line counting, sedangkan analisisi mineral liat dilakukan dengan alat difraktometer sinar-X (XRD). Untuk analisis dengan XRD sebelum dianalisis terlebih dahlu contoh dijenuhkan dengan $\mathrm{Mg}^{++}, \mathrm{Mg}^{++}+$glycerol, $\mathrm{K}^{+}$dan $\mathrm{K}^{++}+$pemanasan pada suhu $550{ }^{\circ} \mathrm{C}$ selama satu jam. Analisis mineral pasir dilakukan pada pedon P2, P4, P5 and P6, sedangkan analisis mineral liat dilakukan secara selektif pada semua pedon. 
Tabel 3. Komposisi mineral fraksi pasir dari beberapa pedon Vertisol

\begin{tabular}{lcccccccccccccccc}
\hline \hline Pedon & Kedalaman $(\mathrm{cm})$ & $\mathrm{Op}$ & $\mathrm{Ku}$ & $\mathrm{Lm}$ & $\mathrm{Fb}$ & $\mathrm{Gv}$ & $\mathrm{An}(\%)$ & $\mathrm{Sn}$ & $\mathrm{Or}$ & $\mathrm{Bi}$ & $\mathrm{Gr}$ & $\mathrm{Ep}$ & $\mathrm{Am}$ & $\mathrm{Au}$ & En & $\mathrm{Hi}$ \\
\hline P2 & $0-18$ & 5 & 6 & 1 & 2 & 2 & 53 & - & - & - & - & - & 22 & 3 & - & 6 \\
& $18-36$ & 3 & 3 & 1 & 3 & 3 & 59 & - & - & - & - & - & 19 & 3 & - & 6 \\
& $36-56$ & 20 & 3 & 1 & 0 & 1 & 37 & - & - & - & - & - & 26 & 4 & - & 8 \\
& $56-88$ & 8 & 6 & 4 & 3 & 3 & 51 & - & - & - & - & - & 19 & 2 & - & 4 \\
& $88-105$ & 10 & 5 & 1 & 2 & 3 & 52 & - & - & - & - & - & 23 & 1 & - & 3 \\
& $105-130$ & 16 & 6 & 2 & 2 & 2 & 38 & - & - & - & - & - & 29 & 3 & - & 2 \\
\hline P4 & $0-8$ & 47 & 35 & - & - & - & - & - & - & 2 & 5 & - & 2 & - & 9 & - \\
& $24-48$ & 41 & 39 & 2 & - & - & - & - & - & 2 & 4 & - & - & - & 12 & - \\
\hline P5 & $0-22$ & 1 & 78 & 1 & 12 & - & 5 & 1 & - & - & - & 2 & - & - & - & - \\
& $22-43$ & 2 & 69 & 1 & 20 & - & 4 & 1 & - & - & - & 3 & - & - & - & - \\
& $43-62$ & 1 & 76 & - & 13 & - & 6 & 1 & - & - & - & 3 & - & - & - & - \\
& $62-89$ & 1 & 67 & 1 & 22 & - & 4 & 1 & - & - & - & 4 & - & - & - & - \\
& $89-110$ & - & 60 & 2 & 27 & - & 5 & 1 & - & - & - & 5 & - & - & - & - \\
& $110-140$ & - & 65 & 2 & 15 & - & 11 & - & - & - & - & 7 & - & - & - & - \\
\hline P6 & $0-15$ & 2 & 59 & 1 & 7 & - & 5 & 6 & 11 & - & - & 4 & 3 & 1 & - & 1 \\
& $15-32$ & 1 & 58 & 2 & 10 & - & 3 & 8 & 12 & - & - & 3 & 3 & - & - & - \\
& $32-53$ & 1 & 52 & 1 & 13 & - & 7 & 9 & 12 & - & - & 2 & 2 & 1 & - & - \\
& $53-71$ & 1 & 53 & 1 & 10 & - & 7 & 9 & 13 & - & - & 3 & 3 & - & - & - \\
& & 15 & -
\end{tabular}

$\mathrm{Op}=$ Opak , $\mathrm{Ku}=$ kuarsa, $\mathrm{Kb}=$ konkresi besi, $\mathrm{Lm}=$ lapukan mineral, $\mathrm{Fb}=$ Fragmen batuan, $\mathrm{Gv}=$ Gelas volkan, Ol= Oligoklas, $\mathrm{An}=$ Andesin, $\mathrm{Or}=$ Orthoklas, $\mathrm{Sn}=$ Sanidin, $\mathrm{Am}=$ amfibol, $\mathrm{Au}=$ Augit, $\mathrm{Hi}=$ Hipersten, $\mathrm{Bi}=\mathrm{Biotit}, \mathrm{Gr}=\mathrm{Garnet}, \mathrm{Ep}=$ Epidot, En= Enstatit

\section{HASIL DAN PEMBAHASAN}

Warna matrik, tekstur dan klasifikasi tanah

Vertisol mempunyai variasi warna matrik yang cukup lebar (Tabel 3) Hue berkisar antara 2,5Y hingga 10YR, value antara 2 hingga 6 dan chroma berkisar antara 0 hingga 4 . Pedon 4 yang berkembang dari bahan peridotit mempunyai warna yang agak kemerahan bila dibandingkan dengan pedon-pedon lainnya, perbedaan ini nampaknya berhubungan erat dengan perbedaan kandungan besi bebasnya.

Semua pedon yang diteliti mempunyai tekstur yang tergolong pada liat berat dengan kandungan fraksi liat $>60 \%$. Tingginya kandungan fraksi liat berhubungan dengan bahan induk tanahnya. Bahan induk Vertisol yang diteliti terdiri atas alluvium napal, peridotit, batu kapur, volkan andesitik dan dasitik yang tergolong pada bahan mudah lapuk, serta endapan banjir dan lakustrin yang memang sudah halus ukuran butirnya. Vertisol yang diteliti telah diklasifikasikan menurut Soil Taxonomy (USDA, 2003), tergolong dalam sub group Typic Hapluderts, Chromic Hapluderts, Chromic Endoaquerts, Paleustollic Chromusters, Udic Haplusterts, Ustic Endoaquerts.

\section{Komposisi mineral \\ Mineral fraksi pasir}

Komposisi mineral fraksi pasir total dari pedon P2, P4, P5 dan P6, disajikan pada Tabel 3 Pedon P2 yang berasal dari aluvium volkan tersusun atas asosiasi andesin dan amfibol, dengan kandungan mineral volkan lainnya seperti opak, hiperstin, augit, gelas volkan dan kuarsa. Komposisi mineral pasir tersebut sangat mencirikan bahan volkan yang besifat andesitik. Nampak disini bahwa jumlah mineral mudah lapuk, seperti gelas volkan, andesin, amfibol, augit dan hiperstin masih sangat tinggi $(>70 \%)$, hal ini menunjukkan bahwa cadangan sumber hara pada Pedon P2 tergolong tinggi. 

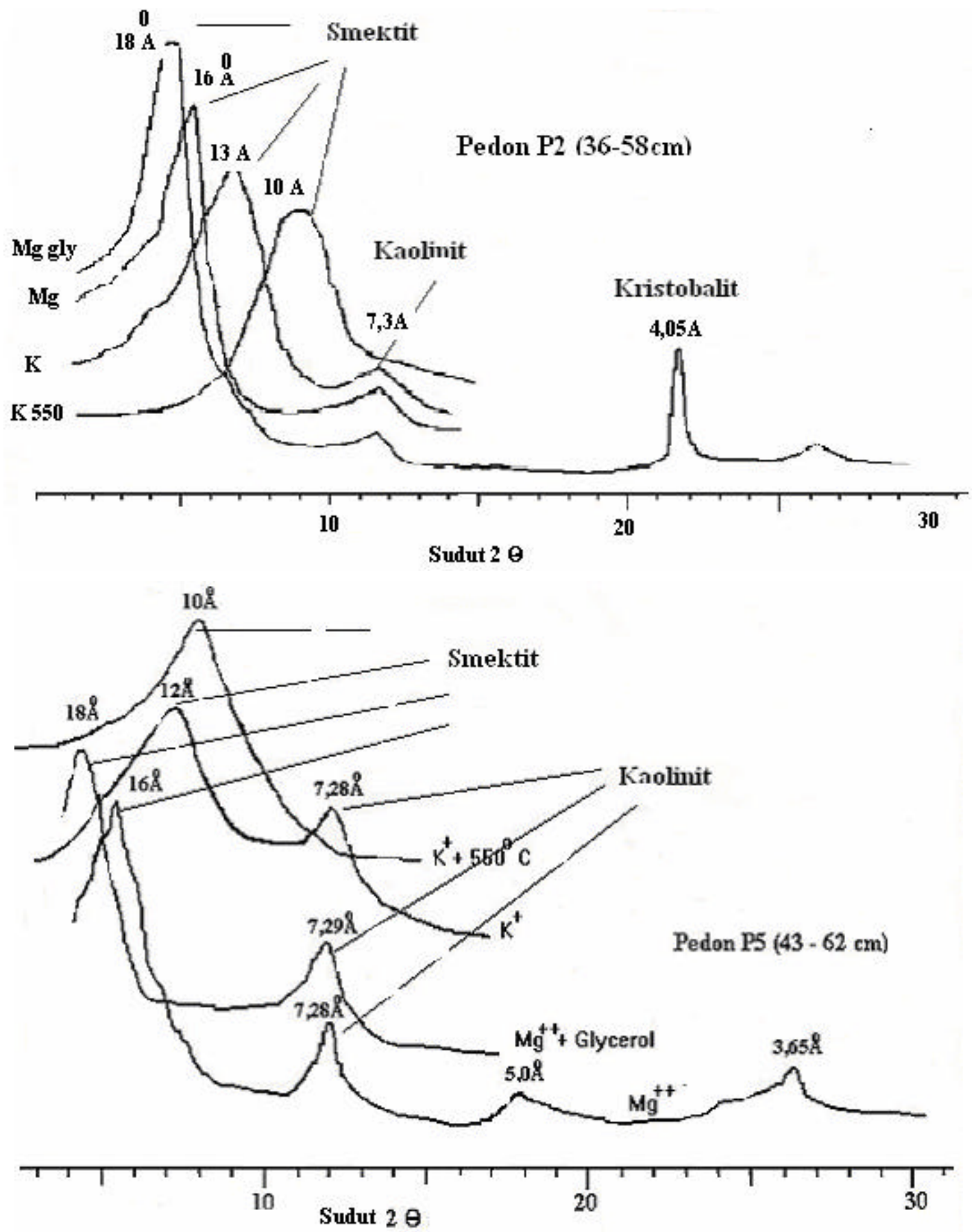

Gambar 1. Difraktogram mineral liat dari Vertisol pedon P2 (Madiun) dan pedon P5 (Pametikarata). 
Tabel 4. Komposisi mineral liat dari beberapa pedon Vertisol.

\begin{tabular}{lcllll}
\hline \hline Pedon & Kedalaman $(\mathrm{cm})$ & Smectit & Kaolinit & Illit & Vermikulit \\
\hline P1 & $0-24$ & ++ & $+*$ & & \\
& $24-49$ & ++ & $+*$ & & \\
& $49-74$ & +++ & $(+)^{*}$ & & \\
\hline P2 & $0-18$ & +++ & $(+)^{*}$ & & \\
& $36-56$ & +++ & $(+)^{*}$ & & \\
& $88-105$ & +++ & $(+)^{*}$ & & \\
\hline P3 & $0-16$ & +++ & $++^{* *}$ & & \\
& $40-66$ & +++ & $++^{* *}$ & & $(+)$ \\
& $106-150$ & +++ & $++^{* *}$ & & $(+)$ \\
\hline P4 & $0-8$ & +++ & - & + & \\
& $24-48$ & +++ & - & + & \\
\hline P5 & $0-22$ & +++ & $(+)^{*}$ & & \\
& $43-62$ & +++ & $(+)^{*}$ & & \\
& $89-110$ & +++ & $(+)^{*}$ & & \\
& $140-170$ & +++ & $(+)^{*}$ & & \\
\hline P6 & $0-15$ & +++ & $++^{*}$ & + & \\
& $32-53$ & +++ & $++^{*}$ & + & \\
& $71-103$ & +++ & $+*$ & $(+)$ & \\
\hline
\end{tabular}

Dominant $=++++$, banyak $=+++$, sedang $=++$, sedikit $=+$, sangat sedikit $=(+), *=$ kristalinitas jelek, $* *=$ kristalinitas jelek

Pedon P4 didominasi oleh mineral opak dan kuarsa. Terdapatnya kuarsa kemungkinan berasal dari penutup (mantle) batuan peridotit. Pedon ini berkembang dari bahan peridotit, merupakan jenis batuan ultabasis yang pada awalnya mengandung lebih dari $30 \%$ mineral olivin sebagai mineral utama. Dalam proses pembentukan tanah, olivin merupakan mineral yang paling dulu habis karena proses pelapukan, sehingga tidak dijumpai lagi pada profil tanahnya. Namun ciri dari bahan ultrabasis masih dijumpai pada mineral enstatit. Cadangan sumber hara pada pedon ini sudah tergolong rendah.

Komposisi mineral faksi pasir dari pedon P5 didominasi oleh mineral kuarsa, dalam jumlah sedikit dijumpai mineral andesin, sanidin dan epidot. Pedon ini berkembang dari bahan aluvium batu gamping, yang seharusnya didominasi oleh mineral kalsit dan dolomit sebagai mineral penyusun utama batu gamping. Kalsit dan dolomit tergolong pada jenis mineral yang sangat mudah lapuk, sehingga sudah tidak dijumpai lagi pada profil tanahnya. Ketika dalam bentuk batu gamping, kandungan mineral kuarsa tergolong sedikit, namun seiring dengan berkurangnya kalsit dan dolomit, kandunan mineral kuarsa jadi lebih menonjol. Cadangan sumber hara pada pedon ini tergolong rendah.

Pedon P6 yang berkembang dari bahan endapan lakustrin didominasi oleh kuarsa, dan dalam jumlah yang lebih sedikit masih dijumpai mineral orthoklas, sanidin dan andesin. Asosiasi mineral tersebut menunjukkan bahwa bahan endapan lakustrin berasal dari bahan volkan yang bersifat masam. Mineral epidot, amfibol, augit dan hiperstin dijumpai dalam jumlah angat sedikit. Cadangan sumber hara pada pedon ini tergolong sedang.

Dari komposisi mineral fraksi pasir terlihat bahwa sebetulnya tidak semua tanah Vertisol mempunyai status cadangan sumber hara yang tinggi, bahkan beberapa menunjukkan cadangan sumber hara yang rendah. 
Tabel 5. Tekstur, C-oranik, pH, besi bebas dan kandungan $\mathrm{P}$ dari beberapa pedon Vertisol.

\begin{tabular}{|c|c|c|c|c|c|c|c|c|c|c|c|}
\hline \multirow[t]{3}{*}{ Pedon } & \multirow{3}{*}{$\begin{array}{l}\text { Kedalaman } \\
\text { (cm) }\end{array}$} & \multicolumn{3}{|c|}{ Tekstur } & \multirow{3}{*}{$\begin{array}{c}\text { Karbon } \\
\text { orgarik } \\
\%\end{array}$} & \multirow{3}{*}{$\begin{array}{c}\mathrm{pH} \\
\mathrm{H}_{2} \mathrm{O}\end{array}$} & \multirow{3}{*}{$\begin{array}{c}\text { Besi } \\
\text { bebas } \\
\% \\
\end{array}$} & \multicolumn{2}{|c|}{$\mathrm{HC} 125 \%$} & \multirow{3}{*}{$\begin{array}{c}\text { P } \\
\text { Olsen } \\
\text { me }\end{array}$} & \multirow{3}{*}{$\begin{array}{c}\text { Retensi F } \\
\% \\
\%\end{array}$} \\
\hline & & $P$ asir & Debu & Liat & & & & $\mathrm{P}_{2} \mathrm{O}_{5}$ & $\mathrm{~K}_{2} \mathrm{O}$ & & \\
\hline & & & $\%$ & & & & & mg pe & $100 \mathrm{~g}$ & & \\
\hline \multicolumn{12}{|c|}{ Typic Hapluderts (alluwium napal) } \\
\hline \multirow[t]{4}{*}{ P1 } & $0-24$ & 2 & 23 & 75 & 1.23 & 7.3 & - & 55 & 78 & 19 & 33 \\
\hline & $24-49$ & 2 & 22 & 76 & 0.45 & 7.3 & - & 41 & 70 & 16 & 29 \\
\hline & $49-74$ & 2 & 23 & 75 & 0.29 & 7.3 & - & 24 & 58 & 23 & 27 \\
\hline & $74-99$ & 2 & 24 & 74 & 0.16 & 7.1 & - & 19 & 58 & 15 & 22 \\
\hline \multicolumn{12}{|c|}{ Chromic $\mathrm{H}$ apluderts (alluwium/coluwium bahan volkan andesitk) } \\
\hline \multirow[t]{6}{*}{$\mathrm{P} 2$} & $0-18$ & 11 & 22 & 67 & 1.11 & 7.0 & 0.59 & 25 & 24 & na & na \\
\hline & $18-36$ & 10 & 26 & 64 & 0.87 & 7.1 & 0.55 & 13 & 12 & na & na \\
\hline & $36-56$ & 12 & 23 & 65 & 0.37 & 7.2 & 0.29 & 4 & 14 & na & na \\
\hline & $56-88$ & 16 & 17 & 67 & 0.26 & 7.2 & 0.25 & 6 & 17 & na & na \\
\hline & $88-105$ & 26 & 13 & 61 & 0.11 & 7.3 & 0.23 & 6 & 13 & na & na \\
\hline & $105-130$ & 51 & 16 & 33 & 0.06 & 7.4 & 0.39 & 20 & 12 & na & na \\
\hline \multicolumn{12}{|c|}{ Chromik Endoaquerts (endapan banjir ber sifat andesitik) } \\
\hline \multirow[t]{5}{*}{ P3 } & $0-16$ & 2 & 10 & 79 & 1.17 & 6.0 & - & 99 & 22 & 38 & na \\
\hline & $16-40$ & 1 & 18 & 81 & 0.86 & 7.4 & - & 33 & 25 & 6 & na \\
\hline & $40-66$ & 2 & 18 & 80 & 0.72 & 7.0 & - & 24 & 54 & 9 & na \\
\hline & $66-106$ & 2 & 28 & 70 & 0.37 & 7.3 & - & 25 & 33 & 4 & na \\
\hline & $106-150$ & 3 & 41 & 56 & 0.24 & 7.1 & - & 28 & 33 & 5 & na \\
\hline \multicolumn{12}{|c|}{ P aleustollic Chromusterts (Ulrabasa peridotit) } \\
\hline \multirow[t]{6}{*}{ P4 } & $0-8$ & 16 & 25 & 59 & 4.46 & 6.2 & 8.44 & 21 & 15 & 11 & na \\
\hline & $8-24$ & 11 & 21 & 68 & 1.89 & 6.1 & 6.81 & 8 & 9 & 7 & na \\
\hline & $24-48$ & 11 & 15 & 74 & 1.70 & 6.3 & 8.26 & 6 & 11 & 4 & na \\
\hline & $48-72$ & 11 & 13 & 76 & 1.38 & 6.4 & 5.55 & 5 & 7 & 4 & na \\
\hline & $72-109$ & 11 & 13 & 76 & 1.12 & 6.3 & 7.88 & 5 & 6 & 3 & na \\
\hline & $109-130$ & 12 & 12 & 66 & 0.97 & 6.4 & 4.57 & 7 & 6 & 3 & na \\
\hline \multicolumn{12}{|c|}{ U dic H aplusterts (alluvium/koluvium dari batu gam ping) } \\
\hline \multirow[t]{7}{*}{ P5 } & $0-22$ & 5 & 18 & 77 & 3.77 & 6.6 & - & 53 & 13 & 20 & 50 \\
\hline & $22-43$ & 4 & 14 & 82 & 1.67 & 6.9 & - & 44 & 11 & 6 & 51 \\
\hline & $43-62$ & 4 & 12 & 84 & 1.53 & 6.8 & - & 42 & 12 & 4 & 48 \\
\hline & $62-89$ & 5 & 16 & 79 & 0.37 & 6.9 & - & 41 & 12 & 1 & na \\
\hline & $89-110$ & 5 & 12 & 83 & 0.41 & 6.8 & - & 43 & 9 & 4 & na \\
\hline & $110-140$ & 4 & 21 & 75 & 0.23 & 7.3 & - & 42 & 11 & 4 & na \\
\hline & $140-170$ & 7 & 11 & 82 & 0.13 & 7.3 & - & 46 & 12 & 3 & na \\
\hline \multicolumn{12}{|c|}{ U stic Endoaquerts (endapan 1akustrine bersifat dasitik) } \\
\hline \multirow[t]{5}{*}{ P6 } & $0-15$ & 8 & 42 & 50 & 1.03 & 6.9 & - & 52 & 43 & 48 & na \\
\hline & $15-32$ & 3 & 28 & 69 & 0.47 & 5.9 & - & 20 & 39 & 10 & na \\
\hline & $32-53$ & 2 & 27 & 71 & 0.40 & 5.5 & - & 16 & 37 & 12 & na \\
\hline & $53-71$ & 3 & 39 & 58 & 0.17 & 7.4 & - & na & na & na & na \\
\hline & $71-103$ & 2 & 30 & 68 & 0.14 & 6.3 & - & na & na & na & na \\
\hline
\end{tabular}


Tabel 6. Kation dapat ditukar dan kapasitas tukar kation dari pedon-pedon Vertisol

\begin{tabular}{|c|c|c|c|c|c|c|c|c|}
\hline \multirow[b]{2}{*}{ Pedon } & \multirow[b]{2}{*}{$\begin{array}{c}\text { Kedal aman } \\
\text { (cm) }\end{array}$} & \multicolumn{3}{|c|}{ Kation dapat tukar } & \multirow{2}{*}{\multicolumn{2}{|c|}{$\begin{array}{lr} & \text { Jumlah } \\
\mathrm{K} & \text { kation } \\
\text { cmol(+)kg tanah } \\
\end{array}$}} & \multicolumn{2}{|c|}{ Kapasi tas tukar kation } \\
\hline & & $\mathrm{Ca}$ & $\mathrm{Mg}$ & $\mathrm{Na}$ & & & Tanah & Liat \\
\hline \multicolumn{9}{|c|}{ Typic H apluderts (Aluvium napal) } \\
\hline \multirow[t]{4}{*}{ P1 } & $0-24$ & 57.31 & 8.92 & 0.61 & 0.73 & 67.57 & 55.64 & 74.39 \\
\hline & $24-49$ & 65.58 & 8.35 & 0.54 & 0.66 & 75.13 & 56.88 & 75.54 \\
\hline & $49-74$ & 46.69 & 8.54 & 0.50 & 0.55 & 56.28 & 57.83 & 77.52 \\
\hline & $74-99$ & 45.50 & 8.98 & 0.50 & 0.53 & 55.51 & 57.79 & 78.52 \\
\hline \multicolumn{9}{|c|}{ Chromic Hapluderts (alluvium/koluvium bahan volkan andesitk) } \\
\hline \multirow[t]{6}{*}{$\mathrm{P} 2$} & $0-18$ & 31.06 & 1.48 & 0.63 & 0.39 & 42.56 & 74.68 & 111.46 \\
\hline & $18-36$ & 31.16 & 9.23 & 0.68 & 0.16 & 41.23 & 74.93 & 117.07 \\
\hline & $36-56$ & 35.06 & 9.40 & 0.65 & 0.19 & 45.30 & 76.15 & 117.15 \\
\hline & $56-88$ & 35.52 & 9.53 & 0.69 & 0.22 & 45.96 & 77.38 & 115.49 \\
\hline & $88-105$ & 31.06 & 9.06 & 0.68 & 0.16 & 40.96 & 72.04 & 118.09 \\
\hline & $105-130$ & 24.70 & 7.95 & 0.62 & 0.13 & 33.40 & 58.24 & 176.48 \\
\hline \multicolumn{9}{|c|}{ Chromik Endoaquerts (endapan banjir bersifat andesitik) } \\
\hline \multirow[t]{5}{*}{$\mathrm{P} 3$} & $0-16$ & 39.02 & 7.41 & 1.46 & 0.26 & 48.15 & 55.09 & 69.73 \\
\hline & $16-40$ & 40.53 & 7.39 & 0.93 & 0.26 & 49.11 & 50.09 & 61.84 \\
\hline & $40-66$ & 38.64 & 9.10 & 0.95 & 0.45 & 49.04 & 49.79 & 62.24 \\
\hline & $66-106$ & 36.00 & 8.73 & 0.75 & 0.26 & 45.74 & 48.42 & 69.17 \\
\hline & $106-150$ & 29.65 & 8.87 & 0.66 & 0.21 & 39.39 & 43.19 & 77.13 \\
\hline \multicolumn{9}{|c|}{ P aleustollic Chromusterts (Ulrabasa peridotit) } \\
\hline \multirow[t]{6}{*}{ P4 } & $0-24$ & 1.40 & 48.30 & 0.10 & 0.20 & 50.00 & 42.90 & 73.00 \\
\hline & $8-24$ & 0.80 & 51.40 & 0.10 & 0.10 & 52.40 & 42.40 & 62.00 \\
\hline & $24-48$ & 0.60 & 59.60 & 0.10 & 0.20 & 60.50 & 59.40 & 80.00 \\
\hline & $48-72$ & 0.30 & 58.40 & 0.10 & 0.10 & 58.90 & 39.30 & 52.00 \\
\hline & $72-109$ & 0.30 & 64.80 & 0.10 & 0.10 & 65.90 & 47.50 & 63.00 \\
\hline & $109-130$ & 0.20 & 76.00 & 0.20 & 0.10 & 76.50 & 61.50 & 93.00 \\
\hline \multicolumn{9}{|c|}{ U dic H aplusterts(alluvium/koluwium dari batu gamping) } \\
\hline \multirow[t]{7}{*}{ P5 } & $0-22$ & 57.94 & 1.38 & 1.62 & 0.24 & 61.18 & 62.79 & 81.55 \\
\hline & $22-43$ & 55.09 & 0.67 & 0.20 & 0.18 & 56.14 & 60.25 & 73.48 \\
\hline & $43-62$ & 51.46 & 0.47 & 0.20 & 0.17 & 52.30 & 57.42 & 68.36 \\
\hline & $62-89$ & 50.99 & 0.35 & 0.30 & 0.20 & 51.84 & 58.35 & 73.86 \\
\hline & $89-110$ & 56.70 & 0.29 & 0.20 & 0.18 & 57.37 & 61.87 & 74.54 \\
\hline & $110-140$ & 55.68 & 0.30 & 0.25 & 0.17 & 56.40 & 59.96 & 79.95 \\
\hline & $140-170$ & 58.59 & 0.31 & 0.20 & 0.18 & 59.28 & 59.73 & 72.84 \\
\hline \multicolumn{9}{|c|}{ U stic Endoaquerts (endapan lakustrin ber sifat dasitik) } \\
\hline \multirow[t]{5}{*}{ P6 } & $0-18$ & 23.55 & 12.15 & 0.47 & 0.86 & 37.03 & 36.13 & 72.26 \\
\hline & $18-40$ & 24.34 & 16.46 & 0.59 & 0.82 & 42.21 & 40.60 & 58.84 \\
\hline & $40-82$ & 24.23 & 17.57 & 0.65 & 0.77 & 43.22 & 44.05 & 62.04 \\
\hline & $82-113$ & 26.99 & 21.60 & 1.10 & 0.49 & 50.18 & 44.19 & 76.18 \\
\hline & $113-160$ & 25.12 & 19.87 & 1.05 & 0.54 & 46.58 & 45.33 & 66.66 \\
\hline
\end{tabular}

Komposisi mineral fraksi liat

Hasil analisis komposisi mineral fraksi liat disajikan pada Tabel 4 dan Gambar 1. Semua pedon yang diteliti didominasi oleh mineral 2:1 smektit. Mineral liat lainnya seperti kalinit, illit dan vermikulit juga dijumpai dalam jumlah yang jauh lebih sedikit.

Pembentukan mineral smektit pada tanah Vertisol memerlukan beberapa kondisi, antara lain, curah hujan harus cukup agar memungkinkan 
terjadinya pelapukan mineral primer tapi tidak terlalu tinggi sehingga tidak tercadi pencucian basa-basa, diperlukan adanya periode kering untuk kristalisasi smektit, drainase yang terhambat untuk menghindarkan proses pencucian hasil pelapukan, dan suhu udara yang tinggi untuk menunjang proses pelapukan (Driessen and Dudal, 1989). Pada kondisi seperti tersebut diatas, smektit dapat terbentuk karena terjadinya akumulasi basa-basa seperti $\mathrm{Ca}^{++}$dan $\mathrm{Mg}^{++}$, dan juga akumulasi silika pada pH diatas netral (Jackson, 1968; De Coninck, 1974).

Komposisi mineral liat pada Vertisol yang tidak hanya smektit saja, melainkan juga terdapat kaolinit, illit dan vermkulit, sesuai dengan pernyataan dari Allen and Hajek (1989) bahwa smektit dalam tanah dapat berasal dari bahan induk tanah ataupun pembentukan baru dari pelapukan mineral phylosilikat lainnya.

Mineral liat kaolinit pada tanah Vertisol yang diteliti terbentuk dengan beberapa cara yang mungkin berbeda. Pada pedon $\mathrm{P} 1$ dan $\mathrm{P} 2, \mathrm{pH}$ tanah $>7$, kondisi landform pada kedua pedon tersebut tidak menunjukkan adanya proses pencucian basa-basa, dan mineral kaolinit menunjukkan kristalinitas yang jelek (Gambar 1). Berdasarkan data tersebut dapat diduga bahwa kaolinit pada kedua pedon tersebut terbentuk bukan hasil pelapukan smektit, melainkan dari pelapukan awal mineral plagioklas. Pada pedon P3 mineral kaolinit mempunyai tingkat kristalinitas yang baik, dan pedon tersebut terletak pada landform dataran banjir, dengan $\mathrm{pH}$ tergolong netral. Kaoinit pada pedon ini diduga juga bukan merupakan pelapukan dari smektit, tapi merupakan hasil pembentukan di daerah hulu dan terendapkan di daerah dataran banjir. Pada pedon P4 tidak dijumpai kaolinit, tapi terdapat illit dan vermikulit. Kedua jenis mineral ini merupakan hasil pelapukan dari biotit. Mineral biotit sendiri dalam jumlah sangat sedikit masih terdapat pada fraksi pasir.

Terdapatnya kaolinit yang berkristanilitas jelek pada pedon P5 (Gambar1) dan P6 yang mempunyai lingkungan yang agak masam, merupakan hasil pelapukan dari smektit. Kondisi bahan organik rendah dan lingkungan yang agak masam dapat menyebabkan smektit menjadi tidak stabil dan bertranformasi menjadi kaolinit (Wilson and Cradwick, 1972) atau pedogenic chlorite (Borchardt, 1989).

Dominasi smektit pada Vertisol telah menyebabkan tanah ini mempunyai kapasitas tukar kation yang tinggi dan mempunyai kemampuan memegang kation yang berasal dari pemupukan seperti $\mathrm{K}^{+}, \mathrm{NH}_{4}{ }^{+}, \mathrm{Ca}^{2+}+$ and $\mathrm{Mg}^{2+}$. Kapasitas tukar kation dari mineral smektit berkisar antara 47 hingga $162 \mathrm{cmol} \mathrm{kg}_{\mathrm{c}}^{-1}$ (Borchard, 1989).

\section{Sifat fisik dan kimia tanah}

Semua pedon Vertisol yang diteliti mempunyai kandungan fraksi liat $>60 \%$ sehingga digolongkan pada kelas besar butir sangat halus. Tingginya kandungan fraksi liat berkombinasi dengan dominasi mineral smektit merupakan salah satu penyebab sifat Vertisol yang sulit diolah bila basah dan sangat keras bila kering.

Kandungan bahan organik umumnya tergolong rendah, berkisar antara 0.06 hingga $4.46 \%$ dan menurun dengan kedalaman tanah. Kandungan bahan organik lapisan atas pedon P4 dan P5 nampak berbeda dengan lapisan atas pedon lainnya. Perbedaan ini disebabkan oleh perbedaan dalam penutup lahannya. Penutup lahan pada pedon P4 adalah kebun pekarangan, sedangkan pedon P5 adalah rumput dan alang-alang. Sedangkan pedon lainnya adalah sawah.

Reaksi tanah berkisar antara agak masam hingga netral (pH 5.5 to 7.4). Relatif lebih rendahnya nilai $\mathrm{pH}$ pada pedon P6 dibandingkandengan pedon-pedon lainnya berhubungan dengan bahan induk tanahnya. Bahan induk pedon P6 adalah endapan lakustrin dari bahan volkanik bersifat masam yang tercermin pada komposisi mineral fraksi pasirnya. Kenyataan ini agak berbeda dengan pendapat dari FAO (2000) dan Syers et al. (2001) yang menyatakan bahwa $\mathrm{pH}$ dari Vertisol adalah netral hingga alkali.

Besi bebas hanya terdeteksi pada pedon P2 dan pedon P4. Kandungan besi bebas pada pedon P2 berkisar antara 0.23 hingga $0.59 \%$, dan pada pedon $\mathrm{P} 4$ berkisar antara 4.57 hingga $8.44 \%$. Perbedaan ini disebabkan oleh sumber besi bebas yang berbeda. Besi bebas berasal dari pelapukan 
mineral-mineral ferromagnesium, dan kandungan mineral golongan ferromagnesium (olivin, amfibol, piroksin) pada pedon $\mathrm{P} 4$ yang berasal dari bahan endapan peridotit adalah lebih tinggi dari pada pedon P2 yang berasal dari bahan endapan volkan andesit.

Kandungan $\mathrm{P}$ potensial $\left(\mathrm{P}_{2} \mathrm{O}_{5}\right.$ dalam $\mathrm{HCl}$ $25 \% 1 \mathrm{~N}$ ) berkisar dari sangat rendah hingga tinggi (4 hingga $99 \mathrm{mg}$ per $100 \mathrm{~g}$ ). Vertisol dari bahan endapan (P1, P3, P5, dan P6) mengandung $\mathrm{P}$ potensial yang lebih tinggi bila disbanding dengan Vertisol dari bahan volkan dan bahan peridotit (P2 and P4). Pada pedon $\mathrm{P} 2$ dan $\mathrm{P} 4$, rendahnya $\mathrm{P}$ disebabkan oleh bahan induk tanah yang miskin $\mathrm{P}$, sedangkan pada pedon lainnya yang berasal dari bahan endapan, tinginya $P$ mungkin disebabkan oleh pengkayaan dari berbagai sumber bahan penyusun endapan tersebut.

Kandungan $\mathrm{K}$ potensial $\left(\mathrm{K}_{2} \mathrm{O}\right.$ dalam $\mathrm{HCl}$ $25 \% 1 \mathrm{~N}$ ) yang tinggi ditunjukkan oleh pedon $\mathrm{P} 1$, dan sedang ditunjukkan oleh pedon P3 dan P6, serta yang rendah oleh pedon P2, P4 dan P5. Sumber utama $\mathrm{K}$ dalam tanah adalah mineral feldspar (orthoklas, sanidin), sehingga terdapatnya kandungan mineral-mineral tersebut dalam tanah mengindikasikan adanya sumber K. Pada pedon P6 yang mempunyai kandungan $\mathrm{K}$ berkisar antara 37 hingga 43 mg per $100 \mathrm{~g}$ masih terdeteksi adanya mineral orthoklas dan sanidin.

$P$ tersedia yang diekstrak denan pengekstrak Olsen umumnya tergolong rendah, berkisar antara 1 hingga 48 me. Rendahnya ketersediaan $\mathrm{P}$ mungkin dsebabkan sebagian dari $\mathrm{P}$ dierap oleh ation $\mathrm{Ca}^{++}$, kecuali pedon $\mathrm{P} 4$ yang mempunyai kandungan $\mathrm{Ca}^{++}$rendah.

Pada Vertisol yang diteliti, kation dapat ditukar didominasi oleh $\mathrm{Ca}^{++}$, kecuali pedon P4 kation dapat ditukarnya didominasi oleh $\mathrm{Mg}^{++}$. Dominasi $\mathrm{Ca}^{++}$pada pedon $\mathrm{P} 1$ dan $\mathrm{P} 5$ disebabkan oleh bahan induk tanah yang bersifat karbonatan (napal dan batu gamping), sehingga perbandingan $\mathrm{Ca} / \mathrm{Mg}$ lebih besar dari pedon P2, P3, dan P6 yang bahan induknya dari bahan volkan. Pada pedon P4 tanahnya berkembang dari bahan peridotit yang mengandung lebih dari 30\% mineral olivin. Olivin sangat kaya akan $\mathrm{Mg}$ dan bersama augit merupakan sumber utama $\mathrm{Mg}$ pada batuan peridotit. Susunan kation dari Tanah-tanah Vertisol yang diteliti ternyata sangat dipengaruhi oleh bahan induk tanahnya.

Kandungan $\mathrm{Na}$ dapat tukar hampir sama pada pedon-pedon Vertisol kecuali pedon P4 dan P5. Sumber utama Na dalam tanah adalah mineral plagioklas, baik pedon P4 maupun P5 yang kandungan $\mathrm{Na}$ dapat tukarnya paling rendah disebabkan karena bahan induk kedua pedon tersebut berturut-turur dari peridotit dan batu gamping miskin akan mineral plagioklas (Tabel 5). Kandungan $\mathrm{K}$ dapat ditukar yang berbeda adalah pada pedon P1 dan P6, karena relatif lebih tinggi dari pedon lainnya dan diduga penyebabnya adalah adanya kandungan mineral yang berfungsi sebagai sumber K, seperti orthoklas dan sanidin.

Kapasitas tukar kation tanah maupun liat pada semua pedon Vertisol yang diteliti tergolong tinggi hingga sangat tinggi, kapasitas tukar kation tanah berkisar antara 36.13 hingga $77.38 \mathrm{cmol}(+) \mathrm{kg}^{-1}$, dan kapasitas tukar kation liat berkisar antara 52.00 hingga $176.48 \mathrm{cmol}^{+}+\mathrm{kg}^{-1}$ (Tabel 6). Tingginya nilai kapasitas tukar kation lebih banyak dipengaruhi oleh dominasi smektit. Kapasitas tukar kation dari mineral smektit berkisar antara 47 hingga 162 me per $100 \mathrm{~g}$ (Borchard, 1989).

\section{KESIMPULAN}

Komposisi mineral fraksi pasir dari Vertisol bervariasi, tergantung dari bahan induknya. Vertisol dari bahan volkan andesitik didominasi oleh opak dan asosiasi andesin-amfibol, dari peridotit didominasi oleh mineral opak, dari batu gamping didominasi kuarsa, dan dari endapan lakustrik didominasi dari bahan volkan masam kuarsa, sanidin dan orthoklas. Komposisi fraksi liat sama untuk semua pedon, didominasi oleh mineral smektit.

Dominasi kation dapat tukar pada Vertisol dipengaruhi oleh jenis bahan induk tanahnya. Vertisol yang dipengaruhi oleh bahan volkan (pedon P2, P3, dan P6) susunan kation dapat ditukar didominasi oleh $\mathrm{Ca}^{++}$diikuti oleh $\mathrm{Mg}^{++}$, yang dipengaruhi oleh batu kapur (pedon P1 dan P5) 
didominasi oleh kation $\mathrm{Ca}^{++}$saja, sedangkan yang dari bahan ultrabasis peridotit ( $\mathrm{P} 4)$ didominasi oleh $\mathrm{Mg}$.

Tingginya kandungan kation $\mathrm{Ca}$ maupun $\mathrm{Mg}$ perlu mendapat perhatian, disamping pengelolaan air agar tanah tidak menjadi kering, rekah-rekah dan mengeras.

\section{DAFTAR PUSTAKA}

Allen, B. L., and B. F. Hajek, 1989. Mineral occurrence in Soil Environments. p 200-264. In Dixon, J. B., and S. B. Weed (Eds). Soil Sci Soc Of Amer., Madison, Wisconsin, U. S. A.

Borchardt, G. A. 1989.Montmorillonite and other Smectite minerals. p 293-330. In J. B. Dixon and S. B. Weed (Eds.). Minerals in Soil Environments. Soil Sci. Of Amer., Madison, Wisconsin, USA.

De Coninck. F. 1974. Physico-chemical aspects of pedogenesis. State Univ. of Ghent

Deckers, J., O Spaargaren and F. Nachtergaele. 2001. Vertisols: Genesis properties and soilscape management for sustainable development. p. 3-20. In Syers, J. K, F. W. T. Penning De Vries, and P. Nyamudeza (Eds): The Sustainable Management of Vertisols. IBSRAM Proceeding No. 20.

Driessen, P. M., and R. Dudal (Eds). 1989. Lecture notes on the geography, formation, properties, and use of the major soils of the world. Agricultural University, Wageningen.

Dudal, R. and H. Eswaran. 1988. Distribution, properties and classification of Vertisols. In L. P. Wilding and R. Puentes (Eds), Vertisol: Their distribution, properties, classification and management. SMSS Technical Monograph 18, Texas A\&M University, College station, TX,pp

Eswaran, H. and T. Cook. 1988. Classification and management- related properties of Vertisols. p. 431. In Jutzi, S., I. Haque, J. McIntire, and J. Stares. (Eds): Proceeding of a Conference held at ILCA, Addis Ababa, Ethiopia, 31 August to 4 September 1987
FAO. 2000. Vertisols. http:/www.fao.org/ag/agl/ prosoil/verti.htm. Last update 21 August 2000.

Fanning, D. S., and M. C. B. Fanning. 1989. Soil. Morphology, Genesis, and Classification. John Wiley and Sons, New York.

Hikmatullah, B. H. Prasetyo, dan M. Hendrisman. 2002. Vertisol dari daerah Gorontalo: Sifatsifat fisik-kimia dan komposisi mineralnya. Jurnal Tanah dan Air . 3 (1) : 21-32.

Jackson, M. C. 1968. Weathering of primary and secondary minerals in soil. Trans. Int. Cougr. Soil Sci., $9^{\text {th }}$ (Adelaide, Aust) 4: 281-292.

Mukanda, N. and A. Mapiki. 2001. Vertisols Management in Zambia. p. 129-127. In Syers, J. K, F. W. T. Penning De Vries, and P. Nyamudeza (Eds): The Sustainable Management of Vertisols. IBSRAM Proceedings No. 20.

Mulyanto, D., M. Nurcholis, dan Triyanto. 2001. Minertalogi Vertisol dari bahan induk tuf, napal dan batupasir. Jurnal Tanah dan Air . 2 (1) : 38-46.

Prasetyo, B. H., H. Sosiawan, and S. Ritung. 2000. Soil of Pametikarata, East Sumba: Its suitability and constraints for food crop development. Indonesian Journal of Agricultural Science. 1 (1) : 1-9.

Prasetyo, B. H., M. Soekardi, dan Subagjo.H. 1996. Tanah-tanah sawah intensifikasi di Jawa: Susunan mineral, sifat-sifat kimia dan klasifikasinya. Pemberitaan Penelitian Tanah dan Pupuk, $14: 12$ - 24.

Ristori, G. G., E. Sparvalie, M. deNobili, and L. P. D'Aqui. 1992. Characterization of organic matter in particle size fractions of Vertisols. Geoderma. 54: 295-305.

Soil Survey Laboratory Staff. 1991. Soil Survey Laboratory Methods Manual. SSIR Number 42 Version 1.0. United States Dept. of Agric. Washington, DC.

Soil Survey Staff. 2003. Keys to Soil Taxonomy. USDA,Natural Research Conservation Servis. Ninth Edition. Washington D. C.

Subagjo, H. 1983. Pedogenesis dua pedon Grumosol (Vertisols) dari bahan volkanik 
gunung Lawu dekat Ngawi dan Karanganyar. Pemberitaan Pen. Tanah dan Pupuk, No.2:8-18.

Subagyo, H., N. Suharta dan A. B. Siswanto. 2004. Tanah-tanah pertanian di Indonesia. Hlm 2166. Dalam A.Adimihardja et al (Eds). Sumberdaya Lahan Indonesia dan Pengelolaannya. Puslitbangtanak. Cetakan kedua.

Sudjadi, M., I. M. Widjik, dan M. Soleh. 1971. Penuntun analisa tanah. Publ. LPT No. 10, Bogor
Syers, J. K., P. Nyamudeza, and Y. Ahenkorah. 2001. Sustainable nutrient management of Vertisols. p. 43 - 55. In Syers, J. K, F. W. T. Penning De Vries, and P. Nyamudeza (Eds): The Sustainable Management of Vertisols. IBSRAM Proceedings No. 20.

Van Wambeke, A. 1992. Soil of the Tropics. Properties and Appraisal. McGraw-Hill. Inc, New York

Wilson, M. J., and P. W. Cradwick. 1972. Occurrence and interstratified kaolinitemonmorillonite in some Scottish soils. Clay Miner. 9: 435-437. 